\title{
The Dynamics of an Effective English Teacher Quality as Perceived by English as Foreign Language Teachers
}

\author{
Yenus Nurie \\ Department of English Language and Literature, Bahir Dar University, Bahir Dar, Ethiopia, P.O.B. 79
}

\begin{abstract}
A large body of research investigated teachers' preference regarding teacher qualities in the first or second language settings. However, little is known about the unique qualities of an English teacher in a foreign language context. This study investigated the perceptions of 44 English instructors regarding the best qualities of an effective English teacher and examined if the participants' education level affects their perceptions using a questionnaire at Bahir Dar University, Ethiopia. The results were statistically analyzed based on three themes defining teacher quality: the socio-affective skills, content knowledge or linguistic knowledge and pedagogical knowledge. While the results revealed both congruent perceptions and differing concerns, an overwhelming majority of the participants valued the linguistic quality of an effective English teacher most. The results also revealed MA instructors' limited perception regarding the pedagogical skill although its effectiveness is reiterated in the literature. Apart from differing in their perceptions regarding the value of pedagogical knowledge, the education level didn't potentially affect participants' perception about what they felt an effective EFL teacher needs to possess regarding the two nominated themes in this study. The study suggests that the benefits of the three qualities of an English teacher should be entirely taken together to enhance student learning. The pedagogical and research implications of the results were presented.
\end{abstract}

Keywords: effective, perception, content, pedagogical, socio-affective

DOI: $10.7176 /$ JLLL/70-03

Publication date:July $31^{\text {st }} 2020$

\section{Introduction}

Quality education is critical and increasingly important in higher education in the globalized world where it provides a competitive advantage both in the academic or work areas. Educational experts differed widely on what constitutes quality of higher education. While some of the scholars narrowly defined it with regard to the school managers and academic staff that teach students and how students are taught (Longanecker \& Blanco, 2003), others precisely defined it emphasizing more on the importance of the academic staff in resource rather than performance terms, such as individual reputation, number of publications, and number of courses taught in higher education where school managers could be considered as problems of coordination (Koslowski, 2006).

It is a widely held belief that how teachers perceive themselves in the role of teaching and education as a community of practice has been essential to the understanding of the connection between teacher quality and personal attributes (Thompson, 2016). Strong (2011) also maintained that teacher effectiveness improves student academic outcomes. Generally, teachers are inseparable parts of education and they have highly significant roles in the quality of teaching and raising successful learners (Dincer, Goksu, Takkac, \& Yazici, 2013). A consensus is not yet developed in the literature around the conceptualization of effective teaching as the term "effective" is interpreted differently by various researchers in different fields such as education, medicine, science and law (Dinçer, et al., 2013). Accordingly, this study defines effective teaching as "being successful in producing a desired or intended result" (Oxford Advanced Learner's Dictionary, 2006).

The conceptualization of quality and factors that affect quality education has received considerable attention in the literature. Most of the empirical studies have capitalized teacher quality as the single most important variable related to student achievement (Strong, 2011), and the direct relationship between teacher ability and student academic achievement has been documented (Danielson, 2007; Hargreaves \& Fullan, 2012; Watson, Miller, Davis $\&$ Carter, 2010). Others found that effective teaching helps not only teachers to improve their personal qualities but also enhance the image of the teaching institutions and teaching effectiveness could be achieved when EFL teachers establish better interpersonal relationship or rapport with their students (Al-Tameemy, 2019).

A remarkable advance in the teaching profession research has identified specific attributes that teachers should possess in relation to teacher quality (Noddings, 2012). Some of the most common components that describe an effective teacher are personal attributes of teachers, pedagogical knowledge and practices, teacher qualifications and teacher effectiveness at improving student performance (Thompson, 2016). The socio-affective skills include motivating and encouraging learner, interacting with the learner and promoting effective educational processes, expecting and responding student needs, etc. The second category concerns the mastery of the target language, using various teaching techniques as indicators of language teaching effectiveness (Shishavan, Sadeghi, 2009). The pedagogical knowledge that includes the ability to maintain classroom management, deliver lessons and motivate students to learn better was chosen as the most valuable characteristics of an effective EFL teacher 
by participants of numerous studies (Arıkan et al., 2008; Aydın et al., 2009; Borg, 2006; Cheung, 2006).

In line with the notion that quality teaching is a key to enhance student learning educational research has revealed full of inspiring ideas regarding the attributions of various teacher qualities. It is recognized that effective teaching requires multiple approaches, so superlatives as 'the best' should not be used in reference to effective teaching. A large body of research has reported the comparison results of the three categories of teacher quality: the socio-affective skills, pedagogical knowledge, subject-matter knowledge (Arıkan, 2010; Dincer, et. al., 2013; Thompson, 2016, \& Strong, 2011). Few studies have reached a conclusion that showed that teachers' socioaffective skills as the most essential characteristics (Arikan, Taşer \& Saraç-Süzer, 2008; Borg, 2006) although others contested their views and have come up with teachers' pedagogical knowledge as the best practice and the best value of an effective teacher (Arıkan et al., 2008; Aydın et al., 2009; Borg, 2006).

Emphasizing on the role of a wide range instructional methods to quality education, some studies have placed the significance of classroom management as one of the most encapsulated factors that attribute student academic achievement (Van Tartwijk \& Hammerness, 2011; Wang \& Degol, 2016). However, this result has also received a pervasive response from research report that showed mastery of subject matter as a more remarkable portrait of an effective teacher (Arıkan, 2010; Shishavan \& Sadeghi, 2009). Overall, regardless of recent research results, no consensus has been reached on the credibility of the results as teaching qualities cannot be accurately measured by teachers' self-reports that could be realized due to teachers' perceptual understanding about how socially desirable the factors are for them (Van de Vijver \& He, 2014).

It has been recognized that instructional quality is fundamental to student learning, and understanding a great deal about teachers' perceptions, beliefs and attitudes about their profession, which is linked with their practices, is an important step to improve student learning outcomes. A plethora of research has consistently provided considerable attention to teacher beliefs and disclosed that although teacher belief is one of the determinants of education quality, teachers' practices do not always reflect their beliefs (Borg, 2006; Farrell \& Kun, 2008). Focusing specifically, CELTA (Certificate in Teaching English to Speakers of Other Languages) categorized the different categories of an effective EFL (English as a Foreign Language) teacher as Learners and teachers, and the teaching and learning context, Language analysis and awareness and Developing teaching skills and professionalism.

These unique EFL teacher characteristics were used as a conceptual framework to understand EFL teachers' views regarding the qualities of an effective EFL teacher since they can be specifically accommodated within the TEFL (Teaching English as a Foreign Language) discipline rather than using its generic conception pertinent to a set of general teaching skills. This study reviewed previous research that showed various qualities of an effective English teacher to help examine unique professional qualities of an English teacher in teaching English as a foreign language context. This study also provided solid empirical foundation of similar taxonomies on the basis of previous studies to help integrate and analyze the data with the empirical evidence reviewed from similar studies.

From this perspective, therefore, learners and teachers, and the teaching and learning context are related to applying a contextualized approach or the socio-affective skill (Park \& Lee, 2006). In line with this expectation, Jyh (2013) maintained that communication is an interactive process that gives space for students to interact, help each other, carry out the responsibility, build confidence, and so on (Cited in Othman, Jamian, Sabil1, Said \& Omar, 2020). The second category of EFL teacher quality as suggested in the literature is Language analysis and awareness, which includes the mastery of the English language, grammar, pronunciation, etc. English is the language of science in Ethiopia where it has the status of English as a Foreign Language (EFL) in the country's curriculum, so it is a strongly needed language in Ethiopia (Medhanit, 2020). The third category includes developing teaching skills and professionalism or pedagogical knowledge (Park \& Lee, 2006). In this global context, the classroom pedagogy used by teachers is consistently seen as the crucial variable for improving learning outcomes' and is critical in any reform to improve quality (UNESCO, 2005).

\subsection{Theoretical Framework}

This study is informed by the Professional Learning Community (PLC) model. The model elucidates teaching and learning a language as a social embedded activity and experience that requires the interaction between the learner and the teacher. Loughran (2010) claimed that high-quality learning needs students to consent and requires the active engagement of both the student and the teacher. Emphasizing the pedagogical objectives embedded with the professional knowledge that can be used enhance student learning, Loughran (2010) further maintained that teaching for understanding is built on cognitive, affective, and social to transform learning into meaningful actions that are designed and managed carefully.

Professional Learning Community (PLC) is a practice that is a suggested model in the language learning literature to be continuously implemented for a long period of time to yield student achievement, particularly as Dufour and Eaker (2008) posit, the educator must give high commitment in doing works through collaboration especially in inquiry collective activity and action research to produce better findings (Cited in Othman, Jamian, Sabil1, Said \& Omar; 2020). The authors explained the implementation of PLC suggesting five dimensions for 
student's academic achievement; however, this study will take only two of them, which were found to suit the purpose of the study, and these are comprehension and strategy dimensions.

Bangeni and Kapp (2017) explained that the comprehension dimension includes knowledge sharing, vision and missions as well as values that help develop a clear picture of the collaborative work that educators can do in PLC model. This could be demonstrated by the interactive sessions that include modeling, collaborative routines, professional behaviors, and collegial practices that are crucial to holding productive PLC meetings (Cited in Othman, et al., 2020). The other key element that educators were suggested to attain the intended objective was the implementation of strategy dimension in the classroom where an educator who implements the practices of PLC to continuously identify the best teaching strategy to enhance student achievement. The wish will come true if educators perform their works in an environment that encourages collaboration (Hargreaves \& Fink, 2018).

The Professional Learning Community (PLC) model assumes that active participation in a PLC reinforces teaching practices and enhances student learning (Supovitz, 2002; Vescio, Ross \& Adams, 2008). The theory underscores the importance of a social instructional network as well as the psychological acts of the teacher in the classroom. To illustrate, the classic theory of PLC model postulated that the learning should be embedded with social activities that focus the essence of social and collaborative aspects of learning. Research has consistently reported the significant, positive correlations between teacher quality and student achievement (Rivkin, Hanushek, Kain, 2005). Central to this research was examining the preference of teacher quality as perceived by university level English instructors as it is hoped to help educators conceptualize the best qualities of English teachers and understand student expectations and needs and prepare teacher professional courses relevant to an effective ELT teacher enshrined in the literature.

This study emanates from the premise of the PLC model as this model reiterates collaborative approach as a means of meaning construction, which explains the relevance of the theory into bringing quality teaching, which is defined as when activities, procedures, and strategies are developed and used by teachers to encourage selection, attending and processing and when they use a particular teaching approach for a particular reason in the actual teaching practice (Loughran, 2010). Thus, the theoretical framework used in this study defines effective teaching as a contextualized social practice, and hence teaching as a social practice inevitably involves interaction of teacher with students, students to students, all of which are organized by an effective English teacher. In light of this theoretical framework, therefore, teacher qualities are conceptualized as unique characteristics of portrayed by an effective English language teacher. In a nutshell, this study is based on the central theme of the PLC model that assumes the vitality of encouraging, motivating and engaging their students in the teaching learning process.

\subsection{Rationale for the Study}

This study examined the perceptual understanding of EFL instructors about the best qualities effective EFL teachers because of the potential of this psychological variable in improving learner academic achievement. This study has important implications for the effectiveness of English instruction in higher education where despite the research evidence that has consistently revealed the high demands and expectations of English language for academic achievement, the Ethiopian students' limited ability to understand English in various education levels were reported (Medhanit, 2020; Mekasha, 2007).

Another issue that may need extra attention in this context is teachers' effectiveness in teaching English. A number of reports have noted that the dearth of effective English language teachers has resulted in the students' weak English performances ( Berhane \& Mishra, 2018). It is also important to note that this failure may be linked to the results of teachers' lack of perceived understanding about the good qualities of an effective English teacher which is more deeply embedded in the quality of the teacher. Thus, this study may be used as a basis for better informed policy making and educational practices.

Unlike previous studies that focused on the general characteristics rather than subject-specific of English teacher qualities, the present study sought to understand EFL university instructors' perceptions of what constitute the qualities of an effective English teacher using a unique instrument with regard to the particular requirements of teaching English. In light of this assumption, the following two overarching questions were primarily formulated to understand instructors' perceptions regarding the best quality of an English teacher in EFL (English as a Foreign Language) classroom where the results may draw better descriptions and characteristics of good English teacher involving both $\mathrm{PhD}$ and MA in TEFL instructors and may enrich the growing body of research in the area of English teacher quality in higher education.

1. What are the perceptions of instructors regarding the qualities of an effective English teacher?

2. Is there any statistical difference between $\mathrm{PhD}$ and MA in TEFL instructors regarding their perceptions about the qualities of an effective English teacher?

\section{Methods}

\subsection{Participants}

The population of this study was 53 English language instructors who were offering various English language 
courses both undergraduate and postgraduate levels in the 2019/20 academic year at Bahir Dar University, Ethiopia. The sample for this study was purposively selected from EFL instructors who were assigned to teach English courses for academic purposes to help gain information about their perception of what they claimed the qualities of an effective EFL teacher could be in their natural settings. However, an accessible population of 44 participants was drawn from the total instructors in the department of English language and literature either due to unavailability of instructors during data collection, or due to reluctance to participate in the study. Among the participants of this study, $30(68.2 \%)$ of the participants had a PhD degree in TEFL, and 14 (31.8) of the instructors had an MA degree in TEFL. A total of 44 instructors participated in this study taught English for many years ranging from 9 to 30 years in various universities.

\subsection{Research Design}

This study sought to examine what qualities of English teachers are perceived to be more important by English instructors in a foreign language context. The present study employed a descriptive research design incorporating a quantitative research method of data collection. It used a survey questionnaire which was developed with reference to the three literature based themes related to qualities of an effective English teacher, and these are the socio-affective skills, content knowledge or linguistic knowledge and pedagogical knowledge as a framework to guide the study. So as to draw the perceptions of an effective English teacher as perceived by both PhD and MA holder English instructors, the mean scores of EFL teacher qualities were computed in the SPSS Version 23. A ttest was computed to determine if there was a statistically significant difference between both groups regarding their perception about the qualities of an effective EFL teacher.

\subsection{Instrument}

The purpose of the study was to examine EFL instructors' views on what they think an effective English teacher should possess in teaching English language. A questionnaire developed by the researcher on the basis of CELTA guideline Cambridge English Teaching fifth edition consisted of closed-ended items constructed on the five point Likert scale. To ensure the content and face validity of the questionnaire items, the questionnaire was given for two TEFL experts who had doctoral degrees in teaching and research experiences of fifteen years.

The questionnaire items that consist of 18 open-ended items were divided into the three qualities of an EFL teacher as suggested in the literature: Socio-affective skills, content knowledge and pedagogical knowledge. To ensure the reliability of this instrument, pilot test was conducted on other groups of instructors in a similar state university, and was found to have a Cronbach's alpha reliability coefficient of alpha $=.76(\mathrm{n}=44)$. The instructors were asked to rate the degree of the importance of each quality category of an effective teacher as: the least important (1), slightly important (2), moderately important (3) important (4) or very important (5). There was a $100 \%$ response rate from the instructors.

\subsection{Research Procedure}

This study aimed at exploring instructors' views about what they feel the best qualities of an EFL instructor. Thus, prior to the start of administering the questionnaire to the participants, the researcher illustrated the purpose of the survey questionnaire and made a brief explanation on how to respond the items in the questionnaire. Then, it was administered to the 44 EFL instructors who showed their consent to participate in this study. It took 15 minutes to respond to the items and fill in the questionnaire. Following completion of the survey, the questionnaire was finally collected by the researcher.

\subsection{Data Analysis}

The data collected from instructors' responses to the questionnaire items was inserted into an SPSS version 23. Mean scores and standard deviations were used to analyze participants' responses regarding their overall preferences for the quality of an EFL teacher. Inferential statistics was also used to analyze statistically significant differences between the mean scores of $\mathrm{PhD}$ and $\mathrm{MA}$ instructors regarding their preferences for the qualities of an effective EFL teacher. Specifically, a t-test was used to analyze the research question that seeks to determine if education level of instructors affects their perceptions about the qualities of an effective English teacher.

\section{Results}

The results were organized according to the order in which the two research questions were structured: (1) the categories of an ELT teacher quality instructors emphasized and (2) the comparison Preferences of an ELT teacher quality between MA and PhD in TEFL instructors. 
3.1. Categories of English Teacher Quality Instructors Emphasized

Table 1: Instructors' overall perception about the qualities of an ELT Teacher

\begin{tabular}{|c|c|c|c|c|c|}
\hline No. & Quality Sub-Categories & Group & Mean & S.D. & M.D. \\
\hline \multirow{2}{*}{\multicolumn{2}{|c|}{ 1. Socio-affective Skills }} & $\mathrm{PhD}$ & 3.31 & .591 & \\
\hline & & MA & 3.65 & 1.020 & -.349 \\
\hline \multirow{2}{*}{\multicolumn{2}{|c|}{ 2. Linguistic Knowledge }} & $\mathrm{PhD}$ & 4.08 & .603 & \\
\hline & & MA & 3.86 & .489 & .221 \\
\hline \multirow{2}{*}{\multicolumn{2}{|c|}{ 3. Pedagogical Knowledge }} & $\mathrm{PhD}$ & 3.76 & .444 & \\
\hline & & MA & 2.77 & .591 & .987 \\
\hline \multirow{2}{*}{\multicolumn{2}{|c|}{ Total }} & $\mathrm{PhD}$ & 3.71 & .255 & \\
\hline & & MA & 3.24 & .479 & .473 \\
\hline
\end{tabular}

*Notes: *N: 44 S.D.: Standard Deviation, M.D.: Mean Difference

Table 1 showed that, the perceptions of $\mathrm{PhD}$ and MA instructors were highly positive with total means of 3.71 and 3.24 respectively. The results for each category also indicated that the most positive perceptions of $\mathrm{PhD}$ instructors in order of importance were content or linguistic knowledge $(M=4.08)$, pedagogical knowledge $(M=3.76)$, and socio-affective skills $(M=3.31)$. On the other hand, MA instructors rated linguistic knowledge $(M=3.86)$, the social affective skills $(M=3.65)$ and pedagogical knowledge $(M=2.77)$. From the data, we can infer that both the PhD and MA instructors perceived the EFL teacher's linguistic knowledge or the English teacher's adequate command of the subject matter as the first and most important priority.

Table 2: Instructors' Perception Regarding the Socio-affective Skills of an Effective English Teacher

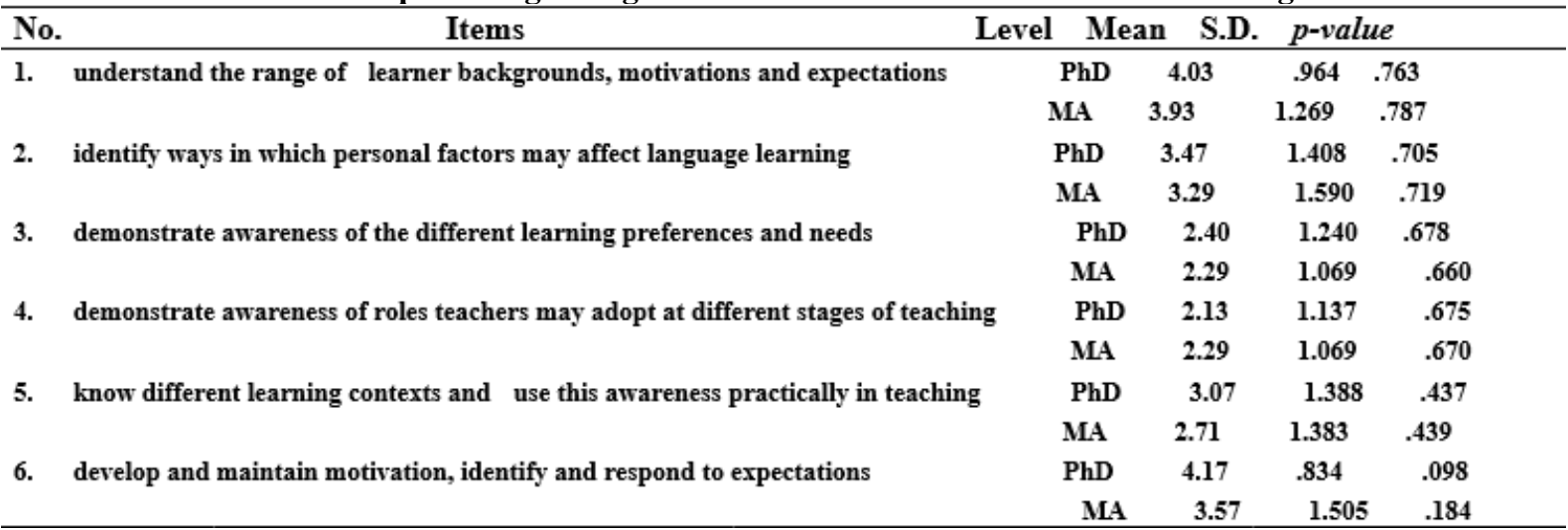

Note: *S.D: Standard Deviation

Table 2 showed that the quality of an English teacher with regard to the socio-affective skills was fairly important as perceived by the instructors. Surprisingly, the participants showed a similar concern on two sub categories and no significant result was realized on all of the sub-categories of this quality. While the ability "to demonstrate awareness of roles teachers may adopt at different stages of teaching" $(M=2.13)$ and "to demonstrate awareness of the different learning preferences and needs" $(M=2.40)$ received the lowest mean values from $\mathrm{PhD}$ participants, MA instructors similarly showed their little or no concern on the ability: "to demonstrate awareness of roles teachers may adopt at different stages of teaching" $(M=2.29)$ and "to demonstrate an awareness of the different learning preferences and needs" $(M=2.29)$. Taken together, the overall mean scores of PhD and MA instructors in this study didn't show any different view with regard to the socio-affective skills of an effective English teacher.

Table 3: Instructors' Perception Regarding the Linguistic Knowledge of an Effective English Teacher

\begin{tabular}{|c|c|c|c|c|c|}
\hline No. & Items & Level & Mean & S.D. & p-value \\
\hline \multirow[t]{2}{*}{1.} & identify key ELT terminology to talk about language and apply this to teaching & $\mathrm{PhD}$ & 4.13 & 1.106 & .001 \\
\hline & & MA & 2.79 & 1.369 & .004 \\
\hline \multirow[t]{2}{*}{2.} & identify grammar rules relating to words, sentences, paragraphs and texts & $\mathrm{PhD}$ & 4.17 & .874 & .012 \\
\hline & & MA & 3.29 & 1.326 & .036 \\
\hline \multirow[t]{2}{*}{3.} & identify the significance of similarities and differences between languages & $\mathrm{PhD}$ & 3.83 & 1.053 & .765 \\
\hline & & MA & 3.71 & 1.541 & .796 \\
\hline \multirow[t]{2}{*}{4.} & make practical use of this awareness in planning and teaching & $\mathrm{PhD}$ & 3.53 & 1.167 & .370 \\
\hline & & MA & 3.86 & .949 & .336 \\
\hline \multirow[t]{2}{*}{5.} & use a range of reference material to analyze language for teaching purposes & $\mathrm{PhD}$ & 4.53 & .730 & .862 \\
\hline & & MA & 4.57 & .514 & .843 \\
\hline \multirow[t]{2}{*}{6.} & use strategies and approaches to develop learners' language knowledge & $\mathrm{PhD}$ & 4.33 & 1.155 & .943 \\
\hline & & MA & 4.36 & .633 & .930 \\
\hline
\end{tabular}

Note: *S.D: Standard Deviation 
Table 3 showed that Both $\mathrm{PhD}$ and MA instructors were overwhelmingly positive about the role of the content/ linguistic competence of an effective English teacher. This value underscores the conclusion that both groups of instructors really appreciated the importance of the linguistic aspect of an English teacher quality most. However, when the sub-categories of the linguistic knowledge of an English teacher quality are further examined, the results showed considerable difference as to the priority of one sub-category. With a high mean score of $(M=4.13)$ and its associated significant value at .001 , this result could be ascribed to: identifying key ELT terminology to talk about language and apply this to teaching in favor of $\mathrm{PhD}$ instructors.

Table 4: Instructors' Perception Regarding the Pedagogical Knowledge of an Effective English Teacher

\begin{tabular}{|c|c|c|c|c|c|}
\hline No. & Items & Level & Mean & S.D. & p-value \\
\hline \multirow[t]{2}{*}{1.} & arrange physical features of the classroom to suit the learners and the lesson & $\mathrm{PhD}$ & 2.80 & 1.324 & .007 \\
\hline & & MA & 4.07 & 1.328 & .005 \\
\hline \multirow[t]{2}{*}{2.} & foster a constructive learning atmosphere and ensure safety regulations & $\mathrm{PhD}$ & 2.87 & 1.252 & .000 \\
\hline & & MA & 4.21 & .579 & .000 \\
\hline \multirow[t]{2}{*}{3.} & set up and manage whole-class, pair, group and individual work as appropriate & $\mathrm{PhD}$ & 3.70 & 1.208 & .436 \\
\hline & & MA & 4.00 & 1.109 & .424 \\
\hline \multirow[t]{2}{*}{4.} & establish and maintain a good rapport with learners at all times & $\mathrm{PhD}$ & 4.33 & .661 & .087 \\
\hline & & MA & 3.79 & 1.424 & .189 \\
\hline \multirow[t]{2}{*}{5.} & choose appropriate moments and strategies for correcting learners' language & $\mathrm{PhD}$ & 3.63 & 1.245 & .568 \\
\hline & & MA & 3.86 & 1.099 & .552 \\
\hline \multirow[t]{2}{*}{6.} & understand the implications of teaching at different levels with limited resources & $\mathrm{PhD}$ & 2.93 & 1.285 & .002 \\
\hline & & MA & 4.21 & .975 & .001 \\
\hline
\end{tabular}

Note: *S.D: Standard Deviation

Recalling from Table 1, it was evident that the instructors' overall perception differed regarding pedagogical knowledge an effective English teacher. In a similar vein, when the sub-categories of the pedagogical knowledge of an effective teacher were compared, out of the six items of an effective English teacher quality regarding the pedagogical knowledge of an effective English teacher, the $p$ values were less than $0.05(P<0.05)$ for three items. These statistically significant differences, with high mean values 4.07, 4.21 and 4.21 for items: to arrange the physical features of the classroom to suit the learners and the lesson, foster a constructive learning atmosphere and ensure safety regulations and understand the implications of teaching at different levels with limited resources respectively could be ascribed to MA instructors.

3.2. Comparison Results of Teacher Quality Preferences between PhD and MA Instructors Table 5: Comparison Results for PhD and MA Instructors Regarding the Three Quality Sub-Categories

\begin{tabular}{llcccc}
\hline No. Quality Sub-Categories & Group & Mean & $\mathrm{S} \mathrm{D}$. & $\mathrm{t}$ & $p$ value \\
\hline 1. Socio-affective Skills & $\mathrm{PhD}$ & 3.31 & .591 & & \\
& $\mathrm{MA}$ & 3.65 & 1.020 & -1.191 & .250 \\
2. Linguistic Knowledge & $\mathrm{PhD}$ & 4.08 & .603 & & \\
& $\mathrm{MA}$ & 3.86 & .489 & 1.196 & .238 \\
3. Pedagogical Knowledge & $\mathrm{PhD}$ & 3.76 & .444 & & \\
& $\mathrm{MA}$ & 2.77 & .591 & 6.178 & .000 \\
& $\mathrm{PhD}$ & 3.71 & .255 & & \\
Total & $\mathrm{MA}$ & 3.24 & .479 & 3.472 & .003 \\
& &
\end{tabular}

Notes: S.D: Standard Deviation, $\mathrm{p}<0.05$ : Significant at $p<0.05$

An Independent sample t-test was used to examine if there was any statistically significant difference between $\mathrm{PhD}$ and MA instructors' perception regarding the three quality categories of an effective English teacher. Table 5 shows that with significant levels of $p>0.05$, the first two quality categories of an English teacher (socio-affective skill and linguistic competence had no significant linear relationship with the education levels of the participants in this study. This implies that there was no statistically significant difference between $\mathrm{PhD}$ and MA instructors' preferences regarding the two categories.

On the other hand, the two groups showed a significant level of preference for the pedagogical knowledge of an English teacher at $\mathrm{p}<0.05$. Thus, it can be reasonably concluded that there was a statistically significant difference between the perceptions of $\mathrm{PhD}$ and M.A instructors regarding this category. Further, with a high mean value of (3.71), and its corresponding significant level of .000, $\mathrm{PhD}$ instructors also differed significantly in their overall preference for the general quality category of an English teacher from MA instructors. This result, which education level showed a statistically significant difference at $\mathrm{p}<0.05$ on one of the three major quality categories, could be ascribed to the pedagogical knowledge in favor of $\mathrm{PhD}$ instructors. 


\section{Discussion}

This descriptive study asserted the role of teacher quality to effective teaching as participants' responses to the key aspects of teacher quality categories ranged from moderate to high value mean values. Considering the positive effect of teachers' perceptions, beliefs and attitudes about their profession, which is linked with their practices, it can be reasonably argued that instructors who participated in this study seemed to make a strong professional commitment to improve student learning outcomes. This analysis results were parallel to a plethora of research that has consistently provided considerable attention to teacher beliefs, perceptions and attitudes towards their profession and disclosed that teacher perceptions and beliefs are the determinants of education quality, and have generally been shown to have a positive impact on student achievement and (Borg, 2006; Farrell \& Kun, 2008).

The results of this study also highlighted both convergence and divergence of EFL instructors' viewpoints with regard to what qualities they claimed to appreciate an English teacher should possess to teach English. The large degree of symmetry between the two groups regarding the linguistic (content) knowledge as their most important category of EFL teacher quality was in substantial agreement with that of a plethora of research that explored the perception of English teachers about what they feel the best quality of EFL teacher and revealed that mastery of the language was the first choice of EFL teachers (Arıkan, 2010; Borg, 2006; Brosh, 2017; Park \& Lee, 2006; Shishavan \& Sadeghi, 2009; Werbinska, 2009).

Other results from the present study concerned with the extent to which education level potentially affects the participants' perceptual priorities of the quality of an effective English teacher. When considering differences, therefore, significant variations were observed between $\mathrm{PhD}$ instructors who rated PCK as the least underlying quality to effective teaching and MA instructors who placed pedagogical knowledge as the most decisive requirement. Linked to these perceptions, the relatively large proportion of $\mathrm{PhD}$ instructors identifying pedagogical knowledge as the least important of quality of an English teacher contrasts with the outcomes of previous studies (Arıkan et al. 2008; Aydın et al. 2009; Borg 2006) which have reiterated the decisive role of pedagogical knowledge to effective English language teaching.

An examination of instructors' perceptions toward the qualities of an effective English teacher demonstrated that both groups of instructors assigned less weight to teacher qualities related to establishing relationship with students. This implies that instructors perceived the socio-affective skills of an English teacher to have a less attribution to effective teaching. Aside from this result, the review of related literature has emphasized the significance of establishing better rapport with learners as an effective EFL teacher (Borg, 2006; Frymier \& Houser, 2009). This indicates that in contrast to the literature; instructors seemed to underestimate the value of establishing personal relationship with their students or did not understand why an effective English teacher should have such skills. Although in the realm of practice, these qualities are explicitly predicated to be good qualities of an English teacher, the possible reason might be that since socio-affective skills require instructors and students to develop a sense of a working alliance for the better academic achievement, the instructors might have been so busy that they might have had lack of time to be available to students in a regular basis.

An integrative examination of this study elucidates that instructors undoubtedly appreciated the qualities of an effective EFL teacher. However, given the instructors' perception was more heavily influenced by the two encapsulated themes than the socio-affective skills of an effective EFL teacher quality; their students might be disadvantaged from the perception of such instructors. Participants' self-reported failure to heed upon establishing rapport with their students is evidently a considerable challenge as this quality enhances better learning by bridging the gap. Linked to this perception, lack of awareness might stem from the misconception about the validity of teacher qualities such as 'nurturing and caring' on developing learner English proficiency. This remark is also contrary to the notion that the primary purpose of teaching at any level of education is to bring a fundamental change in the learner (Tebabal \& Kahssay, 2011). On the whole, the 'unfavorable qualities of an effective English teacher as reported by the respondents in the present study may portray the instructors' actual teaching practices that might have emanated from their learning experience.

\subsection{Conclusion}

A close examination of the results of this study revealed several interrelated themes emerging from the participants commonly agreed perception and differing concerns about the three categorized EFL teacher qualities in this study. Based on the results of this study, the following best qualities and least important features of an EFL teacher as perceived by EFL instructors can be concluded. The results retrieved from the questionnaire revealed that an overwhelming majority of the instructors preferred the linguistic competence of an effective English teacher.

When the participants' expressed priorities were compared, a substantial discrepancy was observed between $\mathrm{PhD}$ and MA instructors' priorities regarding the pedagogical knowledge of an effective English teacher. The MA instructors did not value and react to the pedagogical knowledge although its effectiveness is reiterated in the literature. In contrast, the $\mathrm{PhD}$ instructors expressed significantly higher level of preference for this category. The $\mathrm{PhD}$ instructors might have been enshrined with the essence and art of teaching methodologies due to their frequent exposure in offering postgraduate diploma in teaching, which is offered as a perquisite for being a teacher in the 
university. As a result, their broad experience of eligibility might have affected the instructors' preference for the pedagogical skills than their MA counterparts. In a similar vein, MA instructors little experience to the course might have affected them to set lower priority for this quality category.

As noted above, in placing the 'linguistic knowledge' and the 'socio-affective skills' at the forefront, the MA participants showed heedless perception to the 'pedagogical knowledge' of an effective EFL teacher although its effectiveness is reiterated in the literature. The shallow perception to the pedagogical aspect of an effective English teacher reflected by MA participants in this study cannot be compromised in teaching English as a foreign language context where there is little learner exposure to the language. In this global context, the classroom pedagogy used by teachers is consistently seen as the crucial variable for improving learning outcomes' and is critical in any reform to improve quality (UNESCO, 2005). Thus, this study suggests a more professional development that can raise awareness on the pedagogical necessity of such skills needs to be promoted using discussions, conferences, academic forums and seminars.

Understanding the link between education level and perceived EFL teacher quality was of particular interest in the present study. Linked to this, apart from differing in their perceptions regarding the value of pedagogical knowledge, the education level didn't potentially affect participants' perception about what they felt an effective EFL teacher needs to possess regarding the two nominated themes in this study: linguistic knowledge and socioaffective skills. On the whole, it is important to suggest that all the benefits of the three qualities of an English teacher should be entirely taken together to enhance student learning.

\subsection{Pedagogical and Research Implications}

The present study sheds light on the EFL instructors' perceptual understanding regarding what best qualities an English teacher is believed to possess by examining English instructors' perceptions, and hence will have a great contribution for higher education teaching practices. The implication of this research for EFL students is twofold. Apart from participants' multifaceted perceptions, the instructors' convergent view on the value of linguistic knowledge as the most important EFL teacher quality can be interpreted as promising, for English teachers need to first equip themselves with the command of the language for a better classroom communication. Considering the complexity of learning English as a foreign language, one can infer that the instructors' perceptions towards having good command of the English language may provide a comprehensive picture on the necessity of such teacher quality for effective English teaching, and hence has implications for the EFL pedagogy.

On the contrary, participants' perceptions of the specific categories on the two items that require the ability to couch and deliver lessons appropriately appeared to be the lowest rank. Thus, it is important note from the outset that instructors need to revisit this misalignment as this perception will have a lasting effect on their overall teaching practices, which implies that there is a need to reinforce awareness to bridge this gap. Although further research is needed, the implication is that the unfavorable reactions to good rapport may hurt the learning process. Accordingly, a concerted effort needs to be made to raise instructors' level of awareness and use the results to make sense of it with their teaching practices that may help them strengthen better communication with their students.

This study has the following limitations that need to be taken into account. As this small-scale study dealt with only the instructors' perception about what they felt are the best qualities of an effective English teacher employing a small number of instructors who were currently teaching in a university, it may not be generalized to other universities in Ethiopia. Therefore, similar research should be conducted to better understand the shared grounds of perception of EFL instructors about what the teachers think the best quality of an effective English teacher is in other universities and colleges in Ethiopia. Thus, future research designs should include larger scale samples combining both qualitative and quantitative methods.

This study was also confined to exploring the instructors' views only using a questionnaire. Therefore, there are a good number of reasons for future research to provide a comprehensive picture of the relationships between teacher quality and other variables recruiting large sample size and other data collection instruments. Further, the present study aimed to statistically determine the perceptual understanding of $\mathrm{PhD}$ and $\mathrm{MA}$ English instructors about what they felt the best quality of effective teacher from the three literature based quality categories of an effective English teacher. Thus, this study reiterated triangulating the views of the instructors with their students about what best qualities are expected from an effective English teacher thereby paving the way to make their teaching philosophies more suitable for learners.

\section{Reference}

AlTameemya, F. (2019). A Comparative Study of Teachers' and Students' Perceptions of the Effective English Teacher at Prince Sattam Bin Abdulaziz University International Journal of Innovation, Creativity and Change.5 (2), 1168- 1194

Arıkan, A. (2010). Effective English language teacher from the perspectives of prospective and in-service teachers in Turkey. Electronic Journal of Social Sciences, 9 (31), 209-223. 
Arıkan, A., Taşer, D., \& Saraç-Süzer, H. (2008).The effective English language teacher from the perspectives of Turkish preparatory school students. Education and Science, 33 (150), $42-51$.

Aydın, B., Bayram, F., Canıdar, B., Çetin, G., Ergünay, O., Özdem, Z., \& Tunç, B. (2009). Views of English language teachers on the affective domain of language teaching in Turkey Anadolu University. Journal of Social Sciences, 9 (1), 263-280.

Berhane, G. \& Mishra, D. (2018). Foreign Languages in Ethiopia: History and current status International Journal of Research and Analytical Reviews (IJRAR), 6 (1), 1431-1439.

Borg, S. (2006). The distinctive characteristics of foreign language teachers. Language Teaching Research, 10 (1), 3-31.

Brosh, H. (2017). Perceived Characteristics of the Effective Language Teacher Foreign Language Annals. https://www.researchgate.net/publication/228057240 DOI: 10.1111/j.1944-9720.1996.tb02322.x

CELTAS Syllabus and Assessment Guideline: Cambridge English Retrieved from: https://www.cambridgeenglish.org

Cheung, H. (2006). The measurement of teacher efficacy: Hong Kong primary in-service teachers. Journal of Education for Teaching: International research and pedagogy, 32 (4), 435451.

Danielson, C. (2007). Enhancing professional practice: A framework for teaching (2 ${ }^{\text {nd }}$ ed.). Alexandria, VA: Association for Supervision and Curriculum Development.

Dincer, A., Goksu, A., Takkac, A., \& Yazici, M. (2013). Common Characteristics of an Effective English. The International Journal of Educational Researchers, 4 (3), 1-8.

Farrell, T., \& Kun, K. (2008). Language policy, language teachers' beliefs, and classroom practices. Applied Linguistics, 29 (3), 251----75.

Frymier, A., \& Houser, M. (2009). The teacher-student relationship as an interpersonal relationship. Communication education, 49 (3), 207-219.

Hargreaves, A., \& Fullan, M. (2012). Professional capital: Transforming teaching in every school. New York, NY: Teachers College Press.

Hargreaves, A., \& Fink, D. (2018). Distributed Leadership: Democracy or Delivery ? Journal of Education Administration, 46 (2), 229-240.

Koslowski , F. (2006). Quality and assessment in context: A brief review. Quality Assurance in Education, 14 (3), $277-288$.

Longanecker, D. A., \& Blanco, C. D. (2003). Public policy implications of changing student attendance patterns. New Directions for Higher Education, 121, 51-68.

Loughran, John. J. (2010). What Expert Teachers Do: Enhancing Professional Knowledge for Classroom Practice. Sydney: Allen \&Unwin.

Medhanit, B. (2020). A Needs Analysis of ESP in Textile Engineering Profession in Ethiopian Context, PASAA, $59(1), 181-203$.

Mekasha K (2007). An Exploration of Task Design Procedures of E.E.L. Teachers Ethiopia: A Case Study. $J$. Educ. Dev. 1 (11):81-129.

Noddings, N. (2012). The caring relation in teaching. Oxford Review of Education, 38 (6), 771- 781.

Othman, S, Jamian, A,Sabil1,A, Said, R. \& Omar, R. (2020). Professional Learning Community (PLC): Approach to Enhance Students' Achievement in Language Learning at Public University, Malaysia.Universal Journal of Educational Research 8 (1A): 8-15, http://www.hrpub.org DOI: 10.13189/ujer.2020.081302.

Oxford Advanced Learner's Dictionary (6th Ed.) (2006). Oxford: Oxford University Press.

Park, G.-P., \& Lee, H.-W. (2006). The characteristics of effective English teachers as perceived by high school teachers and students in Korea. Asia Pacific Education Review, 7 (2), 236-248. http://doi.org/10.1007/BF03031547

Rivkin, S., Hanushek, E. \& Kain, J. (2005). Teachers, Schools, and Academic Achievement. Econometrica, 73, (2), 417-458.

Shishavan, H. B., \& Sadeghi, K. (2009). Characteristics of an effective English language teacher as perceived by Iranian teachers and learners of English. English Language Teaching, 2 (4), 130-143.

Strong, M. (2011). The highly qualified teacher: What is teacher quality and how do we measure it? New York, NY: Teachers College Press/Columbia University.

Supovitz, J.A. (2002). Developing communities of instructional practice. Teachers College Record, 104 (2), 127 146.

Tebabal, A. \& Kahssay, G. (2011). "The effect of student-centered approach in improving students' graphical interpretation skills and conceptual understanding of kinematical motion", Lat. Am.J. phy. Edu, 5 (2): $374-$ 381

Thompson, A. (2016), "Perspectives of Teacher Quality: Perceptions from Secondary Educators in Private and Public Schools" Graduate Theses and Dissertations. Retrieved from: http://pilotscholars.up.edu/etd/

UNESCO (2005) Education for All global monitoring report: The quality imperative. Paris: UNESCO. 
Van de Vijver, F. and J. He (2014), "Report on Social Desirability, Midpoint and Extreme Responding in TALIS 2013”, OECD Education Working Papers, No. 107, OECD Publishing, Paris, http://dx.doi.org/10.1787/5jxswcfwt76h-en.

Van Tartwijk, J. \& Hammerness, K. (2011), "The neglected role of classroom management in teacher education", Teaching Education, 22 (2), 109-112, http://dx.doi.org/10.1080/10476210.2011.567836.

Vescio, V., Ross, D. \& Adams. A. (2008). A review of research on the impact of professional learning communities on teaching practice and student learning. Teaching and Teacher Education, 24, 80-91.

Wang, M. \& Degol, J. (2016), "School climate: A review of the construct, measurement, and impact on student outcomes", Educational Psychology Review, 28 (2), 315-352, http://dx.doi.org/10.1007/s10648-015-9319-1.

Watson, S., Miller, T., Davis, L., \& Carter, P. (2010). Teachers' perceptions of the effective teacher. Research in the Schools 17 (2), 11-22.

Werbinska, D. (2009). A profile of effective teacher of English: A qualitative study from Poland. Haccetepe University Journal of Education, 36, 306-315. 